\title{
In Vitro Antimicrobial Efficacy of Fractions from Demakese (Ocimum lamifolium) Leaves Extract from Mekelle Tigray, Ethiopia
}

\section{Teklit Gebregiorgis Amabye ${ }^{1 *}$ and Said Mussa ${ }^{2}$}

${ }^{1}$ Department of Chemistry, Mekelle University College of Natural and Computational Science, Mekelle, Tigray, Ethiopia

${ }^{2}$ Department of Statistics, Mekelle University College of Natural and Computational Science, Mekelle, Tigray, Ethiopia

\begin{abstract}
The aim of the study was to screen the antibacterial activities and phenolic compounds of methanol extracts of the Ocimum lamiifolium available in mekelle Tigray Ethiopia. Crude extract of the leaves methanol were screened for antibacterial activities against S. aureus, Pseudomonas spp. and Escherichia coli. The in vitro antibacterial activity was performed by agar disc diffusion method and this shows that methanol extract of Ocimum lamiifolium revealed an elevated antimicrobial activity against $S$. aureus, E. coli and Pseudomonas spp. The quantitative analysis of phenolic constituents was determined using high-performance liquid chromatography and shows that the phytochemicals found in each extract are rich antioxidants and these extracts can be used as an effective preservative in food industry. The results obtained in the present study suggest that the methanol extracts of Ocimum lamiifolium revealed a significant scope to develop a novel antibacterial herbal formulation and a source of antibacterial drugs.
\end{abstract}

Keywords: Ocimum lamifolium; Antibacterial activity; Methanol extract

\section{Introduction}

The genus Ocimum (Lamiaceae) consists of about 30 Old and New worlds, with some species cultivated in temperate areas. Ocimum lamiifolium Hochst. ex Benth (local name Tossign, Amharic) is mostly found in clearings and edges of primary and secondary mountain forests and bushlands, tall grasslands, abandoned fields, at altitudes between 1200 and $2900 \mathrm{~m}$. Traditionally, the fresh leaves are squeezed and the juice is sniffed to treat cough and cold. The juice is also used as eye rinse to treat eye infections. At the same time, the crushed leaves are put in the nostrils to stop nose bleeding [1].

A huge range of medicinal plants parts is used to extract as raw drugs and they possess varied medicinal properties [2]. While some of these raw drugs are collected in smaller quantities by the local communities and folk healers for local used, many other raw drugs are collected in larger quantities and traded in the market as the raw materials for many herbal industries [3]. Plants used for traditional medicine contain a wide range of substances that can be used to treat chronic as well as infectious diseases. Microbiologists have great affiliation tin screening of medicinal plants for new therapeutics [4]. The active compound of many drugs found in plants are secondary metabolites. The development of drug resistance in recent years the use medicinal plant to evaluate plants possessing antibacterial activity for various diseases is growing [5-7]. Research has been done worldwide on the use of medicinal plants to cause human diseases and extracts of many plant species have been found to be active against many pathogenic bacteria. Aqueous extract of some plants have been reported from time to time to demonstrate antimicrobial activity. The efficacy of various species of medicinal plants against a variety of pathogens has been reported by a number of workers [8-17].

A wide variety of indigenous and minor crops have been utilized for daily consumption since ancient times. The family Labiateae is one of the largest families, which comprises the larger proportion of medicinal plant species. Ocimum is one of the important genera of family Labiateae [18]. Ocimum species often referred toas the "king of the herb. Ocimum lamifolium is an important medicinal herb belonging to family Lamiaceae.

The aim of the present study, however, was to test the antibacterial activities and phytochemical properties of the methanol, extracts of the leaves of O. lamifolium.

\section{Materials and Methods}

\section{Collection of plant species}

The Ocimum lamiifolium was collected from different area of Mekkele City, Tigray, Ethiopia in September, 2015. The species were botanically identified. And the plant material was washed with distilled water.

\section{Extraction of plant material}

Collected leaves of $O$. lamiifolium was washed by distilled water and subjected to shade drying at $25^{\circ} \mathrm{C}$. Then the dried leaves were pulverized to get course powder. $100 \mathrm{~g}$ of the powder was added to $1 \mathrm{~L}(1: 10, \mathrm{w}: \mathrm{v})$ of one solvent types, namely, methanol (absolute) and the mixture was shaked for $48 \mathrm{~h}$ at 120 rotations $/ \mathrm{min}$. The solutions were filtered by Whatman No. 1 filter paper. Finally, the methanol extracts was concentrated under vacuum in a rotary evaporator (Büchi Laboratoriums-Tchnik AG CH-9230 Flawil/Schweiz) to give gummy residues and the crude extracts was then weighed and subjected to an antibacterial activity test.

\section{Tested bacteria}

Antibacterial activity of spices powder extracts was investigated against two gram-negative and two gram positive bacterial isolates, which were obtained from the Hospital Laboratory of Mekelle University, Ethiopia and The tested bacteria, were cultured on Nutrient agar at $37^{\circ} \mathrm{C}$ for $24 \mathrm{~h}$.

\section{Antimicrobial assay}

The in vitro antibacterial activities of the test samples were carried

*Corresponding author: Teklit Gebregiorgis Amabye, Department of Chemistry, Mekelle University College of Natural and Computational Science, Mekelle, Tigray, Ethiopia; E-mail: teklitgeb@gmail.com

Received October 31, 2015; Accepted November 13, 2015; Published November 19, 2015

Citation: Amabye TG, Mussa S (2015) In Vitro Antimicrobial Efficacy of Fractions from Demakese (Ocimum lamifolium) Leaves Extract from Mekelle Tigray, Ethiopia. Nat Prod Chem Res 3: 196. doi:10.4172/2329-6836.1000196

Copyright: (c) 2015 Amabye TG, et al. This is an open-access article distributed under the terms of the Creative Commons Attribution License, which permits unrestricted use, distribution, and reproduction in any medium, provided the original author and source are credited. 
out by disc diffusion method [19,20]. In the disc diffusion method, Muller-Hintonagar was used as culture media and the discs were placed aseptically over the bacterial culture on nutrient agar plates and incubated at $37^{\circ} \mathrm{C}$ for 24 hours [21]. After incubation for 24 hours, the zones of inhibition around the discs were measured by millimeter scale. Discs were impregnated with each treatment and control was assayed on agar medium plate for Pseudomonas spp., Escherichia coli and S. aureus. The diameter of zone of inhibition as indicated by clear area which was devoid of growth of microbes was measured to determine the antibacterial activity. The experiment was repeated two times to confirm the reproducible results. Sterile, blank paper discs impregnated with only sterile ethanol and distilled water served as negative control each time. Standard Gentamycin $(10 \mu \mathrm{g} / \mathrm{disc})$ was used as positive control for comparison of the antibacterial activity. Minimum Inhibitory Concentration (MIC) value of the extracts of the Ocimum lamifolium was determined in present study following the serial dilution technique.

\section{Quantization of phenols using HPLC}

A HPLC system comprising of a vacuum degasser, quaternary pump, auto sampler, thermostated column compartment, and photodiode array detector (PDA) was used for the quantification of individual phenolic compounds. The column, Phenomenex C18 5 $\mu \mathrm{m}(250 \times 4.6 \mathrm{~mm})$, was maintained at $26^{\circ} \mathrm{C}$. Different proportions of solvents such as acetonitrile/water/acetic acid (15:84:0.85) as eluant $\mathrm{B}$ and methanol as eluant $A$ were used for the separation. The multiple gradient used for chromatographic separation consisted of different proportions of eluant A/B (50:50 for 1-5 $\mathrm{min}$, 40:60 for $5-10 \mathrm{~min}$, 30:70 for 10-15 min, and 15:85 for 15-20 min). The flow rate was $1 \mathrm{ml} /$ min, the sample injection volume was $50 \mu \mathrm{l}$, and the chromatogram monitored at $330 \mathrm{~nm}$. The peak purity of the tested sample was determined by comparing its ultraviolet (UV) spectra to that of the reference standards. Quantification was made on the basis of the corresponding peak area recorded by chromatopac c-R6A (Shimadzu). Reference standards were used for the preparation of standard curves.

\section{Statistical analysis}

The result of the antimicrobial activity was expressed as the means obtained from 3 independent analyses. Analysis of variance was used to compare between data. All analyses were performed at $\mathrm{p}<0.05$ using Minitab version 2000 13.1 (Minitab, State College, PA, USA) [11].

\section{Results and Discussion}

The results of the antimicrobial activity of the methanol extract of fresh leaves of Ocimum lamifolium was found sensitive to S. aureus, E. coli and P. aeruginosa. Crude methanol extract produced zone of inhibition $12 \mathrm{~mm}$ and $13.5 \mathrm{~mm}$ against $S$. aureus and $E$. coli respectively and also exhibited highest zone of inhibition $(12 \mathrm{~mm})$ against $P$. aeruginosa (Table 1 ). The MIC value was also determined against the all tested bacteria. The MIC value of methanol extract of Ocimum lamifolium was found to be $200 \mathrm{mg}$ and $100 \mathrm{mg}$ against both S. aureus and E. coli respectively (Table 2).

The plant extracts was found to exhibit a good anti-oxidant activity in the selected in vitro antioxidant assays. Overall, the extracts tend to possess lesser activity in comparison to positive control BHA. Potential activity of all these extracts in the tested antioxidant assays is a promising factor for their application as an effective preservative for the food and cosmetic industries. However, further research would be required before such claims could be proposed with confidence.

The plant extracts shows that the maximum effect was exhibited

\begin{tabular}{|c|c|}
\hline \multicolumn{1}{|c|}{ Name of Microorganism } & Zone of Inhibition (mm) \\
\hline \multicolumn{1}{|c|}{ Methanol extract } \\
\hline Staphylococcus aureus & 13.5 \\
\hline Proteus vulgaris & 12 \\
\hline Pseudomonas aeroginosa & 06 \\
\hline Bacillus subtilus & - \\
\hline Staphylococcus & 05 \\
\hline epidermidis & 01 \\
\hline Streptococcus mutans & 03 \\
\hline
\end{tabular}

Table 1: Antibacterial activity of methanol extract of Ocimum lamifolium.

\begin{tabular}{|c|c|}
\hline \multirow{2}{*}{ Name of Microorganism } & Minimum inhibitory concentration (mg/l) \\
\cline { 2 - 2 } & Methanol extract \\
\hline Escherichia coli & 100 \\
\hline Staphylococcus aureus & 200 \\
\hline Proteus vulgaris & 10 \\
\hline Pseudomonas aeroginosa & - \\
\hline Bacillus subtilus & 20 \\
\hline Staphylococcus epidermidis & 10 \\
\hline Streptococcus mutans & 5 \\
\hline
\end{tabular}

Table 2: MIC of plant extracts against bacterial isolates $(\mathrm{mg} / \mathrm{ml})$.

by Ocimum lamifolium. These results are in parallel with the previous report on Ocimum spp. by ref. [22,23]. However, in the present study the maximum effect of tested plant extracts were showed on E. coli followed by $S$. aureus and $P$. aeruginosa. This result is in contradiction with the report by Pankaj and Puroshottam, revealed that $S$. aureus (a Gram-positive bacterium) was observed as most susceptible bacterium as it was inhibited by extracts of Ocimum spp., Streptococcus pyogenes and Salmonella typhi was found to be resistant to all the extracts tested [24]. The results of present study support the traditional usage of plant and Ocimum lamifolium plant extracts which possess compounds with antibacterial properties that can be used as antibacterial agents in new drugs for the therapy of infectious diseases caused by pathogens and further work may be carried out for pharmacological evaluation.

The quantitative analysis of phenolic constituents in the methanol extract of fresh leaves of Ocimum lamifolium as described in Table 3 the methanol extract of Ocimum species has led to the identification of 6 phenolic compounds (rosmarinic acid, lithospermic acid, vanillic acid, p-coumaric acid, hydroxybenzoic acid, and sinapic acid), which have been described for the first time in these plants were identified by comparison to the retention time and UV spectra of authentic standards and quantitative data were calculated based on their peak area $[25,26]$. In this study, hydroxybenzoic acid was the most abundant component identified in extract in comparison with other phenolic compounds and other compounds (range $=0.14 \pm 0.02 \mathrm{mg} / \mathrm{g}$ dry wt.). This is in general agreement with previously published qualitativequantitative analyses of Lamiaceae species (Shan et al.). This is also in agreement with Jamal Javanmardi and his coauthors, who reported that rosmarinic acid, is the most abundant component in O. basilicum (Javanmardi et al.). The other components such as lithospermic acid (range $=0.04 \mathrm{mg} / \mathrm{g}$ dry wt.), vanillic acid (range $=0.03 \mathrm{mg} / \mathrm{g}$ dry wt.), p-coumaric acid (range $=0.17 \mathrm{mg} / \mathrm{g}$ dry wt.), hydroxybenzoic acid (range $=0.14 \mathrm{mg} / \mathrm{g}$ dry wt.) and sinapic acid (range $=0.02 \mathrm{mg} / \mathrm{g}$ dry wt.) were found. The variation in the distribution of individual phenolic compounds in different country species is possibly due to (1) genotypic and environmental differences (2) choice of parts tested, (3) time of sample collection, and (4) determination methods. It could also be due to the solvent used for the extraction that is, the extraction yield, nature of the compounds and materials from which the compound was 
Citation: Amabye TG, Mussa S (2015) In Vitro Antimicrobial Efficacy of Fractions from Demakese (Ocimum lamifolium) Leaves Extract from Mekelle Tigray, Ethiopia. Nat Prod Chem Res 3: 196. doi:10.4172/2329-6836.1000196

Page 3 of 3

\begin{tabular}{|c|c|}
\hline Analyte & Ocimum lamifolium $\mathbf{~} \mathbf{m g} / \mathbf{g})$ \\
\hline Rosmarinic acid & $0.10 \pm 0.02$ \\
\hline Lithospermic acid & $0.04 \pm 0.01$ \\
\hline Vanilic acid & $0.03 \pm 0.01$ \\
\hline p-Coumaric acid & $0.17 \pm 0.03$ \\
\hline Hydroxy benzoic acid & $0.14 \pm 0.02$ \\
\hline Syringic acid & ND \\
\hline Caffeic acid & ND \\
\hline Dihydroxy phenyl lactic acid & ND \\
\hline Sinapic acid & $0.02 \pm 0$ \\
\hline
\end{tabular}

Table 3: Total phenolic content and quantitative analysis of secondary metabolite content of the Ocimum lamifolium leaves extract.

extracted are strongly dependent on the solvents due to the presence of different concentrations of bioactive compounds with different polarities. Similarly, in Diospyroskaki, the isolation of triterpene acids (barbinervic acid, rotungenic acidand 2, 4-dihydroxyursolic acid) is strongly influenced by the solvent system.

\section{Conclusion}

The present investigation revealed that the extract of Ocimum lamiifolium leaves have potent antimicrobial activity which explains its use in traditional system of medicines. Hence, Ocimum lamiifolium can be employed as a source of natural antimicrobials that can serve as an alternative to conventional medicines. In general the phytochemical analysis of Ocimum lamiifolium species extracts has led to the identification of 6 phenolic compounds (rosmarinic acid, lithospermic acid, vanillic acid, p-coumaric acid, hydroxybenzoic acid, and sinapic acid), which have been described for the first time in these plants. Furthermore, all the plant extracts were found to exhibit a good antioxidant activity in the selected in vitro antioxidant assays. Overall, the extracts tend to possess lesser activity in comparison to positive control BHA. Potential activity of all these extracts in the tested antioxidant assays is a promising factor for their application as an effective preservative for the food and cosmetic industries. However, further research would be required before such claims could be proposed with confidence.

\section{References}

1. Asfaw N, Demissew S (2009) Aromatic Plants of Ethiopia. Addis Ababa: Shama Books 257

2. Adebolu TT, Oladimeji SA (2005) Antimicrobial activity of leaf extracts of Ocimum gratissimum on selected diarrhea causing bacteria in southwestern Nigeria. Afr J Biotechnol 4: 682-684.

3. Adiguzel A, Gulluce M, Sengul M (2005) Antimicrobial Effects of Ocimum basilicum (Labiatae) Extract Turk J Biol 29: 55-160.

4. Ahmad I, Aqil F (2007) In vitro efficacy of bioactive extracts of 15 medicinal plants against ESbL-producing multidrug-resistant enteric bacteria. Microbiol Res 162: 264-275.

5. Amadioha AC (2001) Fungicidal effect of Some Plant Extracts against Rhizoctonia solani in cow pea. Arch Phytopathol 33: 509-517.

6. Bauer AW, Kirby WM, Sherris JC, Turck M (1966) Antibiotic Susceptibility Testing by a Standardized Single Disk Method. Am J Clin Pathol 36: 493-496.

7. Byarugaba DK (2009) Mechanisms of Antimicrobial Resistance. In de J Sosa A Byarugaba DK, Amabile-Cuevas CF, Kariuki S, Okele IN (eds.): Antimicrobial Resistance in Developing Countries 15-26.

8. Carson CF, Hammer KA, Thormar H (2011) Chemistry and Bioactivity of Essential Oils. Lipids and Essential Oils as Antimicrobial Agents, John Wiley \& Sons, Ltd, United Kingdom 204-238.

9. Chiang LC, Ng LT, Cheng PW, Chiang W, Lin CC (2005) Antiviral Activities of Extracts and Selected Pure Constituents of Ocimum Basilicum. Clin Exp Pharmacol Physiol 32: 811-816.
10. Dagne E (2009) Natural Data Base for Africa (NDA) on CD-ROM, Addis Ababa Ethiopia. Specie ID 302.

11. Duke TA (2009) Duke's Handbook of Medicinal Plants of Latin America. CRC Press is an imprint of Taylor \& Francis Group, an Informa business, United States of America.

12. European Committee for Antimicrobial Susceptibility Testing (EUCAST) of the European Society of Clinical Microbiology and Infectious Diseases (ESCMID) (2000) Determination of minimum inhibitory concentrations (MICs) of antibacterial agents by agar dilution. Clinical Microbiology and Infection 6 : 509-515.

13. Gebrehiwot A, Unakal CG (2013) Effect of Aqueous and Ethanolic Extracts of Ocimum lamiifolium and Amaranthus dubius against Bacteria Isolated from Clinical Specimen. Int J Pharm Ind Res 03: 10-14.

14. Goyal R, Kaushik P (2011) In vitro Evaluation of Antibacterial Activity of Various Crude Leaf Extracts of Indian Sacred Plant, Ocimum sanctum L. Br Microbio Res J 1: 70-78.

15. Hakkim F, Arivazhagan G, Boopathy R (2008) Antioxidant property of selected Ocimum species and their secondary metabolite content. J Med Plant Res. 2 250-257.

16. Kashyap CP, Ranjeet K, Vikrant A, Vipin K (2011) Therapeutic Potency of Ocimum Kilimands charicum Guerke - A Review. Global J Pharmacol 5: 191 200

17. Kekuda TR (2012) In vitro Antibacterial Efficacy of Selected Plant Extracts, Streptomycin and their Combination. Asian J Res Chem 5: 791-793.

18. Nakamura V, Ueda-Nakamura T, Bando E, Melo N, Cortez G, et al. (1999) Antibacterial Activity of Ocimum gratissimum L. Essential Oil. Mem Inst Oswaldo Cruz 94: 675-678.

19. Nascimento GF, Locatelli J, Freitas PC, Silva GL (2000) Antibacterial activity of plant extracts and phytochemicals on antibiotic resistant bacteria. Braz Microbiol 31: 247-256.

20. Patil DD, Mhaske DK, Wadhawa GC (2011) Antibacterial and Antioxidant study of Ocimum basilicum Labiatae (sweet basil). J Adv Pharm Educ Res 2: 104-112.

21. Prasannabalaji N, Muralitharan G, Sivanandan RN, Kumaran S, Pugazhvendan SR (2012) Antibacterial activities of some Indian traditional plant extracts. Asian Pacific J Trop Dis 2: S291-S295.

22. Sneha G, Margaret NJ, Sastry P, Jyothi Ch (2011) Evaluation of Antibacteria Activity of Ocimum. Int J Pharmacogn Phytochem Res 3: 89-92.

23. Tchoumbougnang F, Zollo PHA, Avlessi F, Alitonou GA, Sohounhloue DK, et al. (2014) Variability in the Chemical Compositions of the Essential Oils of Five Ocimum Species from Tropical African Area. J Essent Oil Res 18: 194-199.

24. Wiart C (2006) Medicinal Plants of the Asia-Pacific Drugs for the Future? World Scientific Publishing Co. Pvt Ltd., New Jersey.

25. Yilmaz MT (2012) Minimum inhibitory and minimum bactericidal concentrations of boron compounds against several bacterial strains. Turk J Med Sci 42: 14231429.

26. Zuzarte M, Gonçalves MJ, Canhoto J, Salgueiro L (2011) Antidermatophytic activity of essential oils. Science against microbial pathogens: communicating current research and technological advances 1167-1178. 